Atmos. Chem. Phys., 10, 4559-4571, 2010

www.atmos-chem-phys.net/10/4559/2010/

doi:10.5194/acp-10-4559-2010

(c) Author(s) 2010. CC Attribution 3.0 License.

\title{
Black carbon aerosols and the third polar ice cap
}

\author{
S. Menon ${ }^{1}$, D. Koch ${ }^{2}$, G. Beig ${ }^{3}$, S. Sahu ${ }^{3}$, J. Fasullo ${ }^{4}$, and D. Orlikowski ${ }^{5}$ \\ ${ }^{1}$ Lawrence Berkeley National Laboratory, Berkeley, CA, USA \\ ${ }^{2}$ Columbia University/NASA GISS, New York, NY, USA \\ ${ }^{3}$ Indian Institute for Tropical Meteorology, Pune, India \\ ${ }^{4}$ Climate Analysis Section, CGD/NCAR, Boulder, CO, USA \\ ${ }^{5}$ Lawrence Livermore National Laboratory, Livermore, CA, USA
}

Received: 12 November 2009 - Published in Atmos. Chem. Phys. Discuss.: 11 December 2009

Revised: 5 May 2010 - Accepted: 6 May 2010 - Published: 18 May 2010

\begin{abstract}
Recent thinning of glaciers over the Himalayas (sometimes referred to as the third polar region) have raised concern on future water supplies since these glaciers supply water to large river systems that support millions of people inhabiting the surrounding areas. Black carbon (BC) aerosols, released from incomplete combustion, have been increasingly implicated as causing large changes in the hydrology and radiative forcing over Asia and its deposition on snow is thought to increase snow melt. In India BC emissions from biofuel combustion is highly prevalent and compared to other regions, $\mathrm{BC}$ aerosol amounts are high. Here, we quantify the impact of $\mathrm{BC}$ aerosols on snow cover and precipitation from 1990 to 2010 over the Indian subcontinental region using two different $\mathrm{BC}$ emission inventories. New estimates indicate that Indian $\mathrm{BC}$ emissions from coal and biofuel are large and transport is expected to expand rapidly in coming years. We show that over the Himalayas, from 1990 to 2000 , simulated snow/ice cover decreases by $\sim 0.9 \%$ due to aerosols. The contribution of the enhanced Indian BC to this decline is $\sim 36 \%$, similar to that simulated for 2000 to 2010. Spatial patterns of modeled changes in snow cover and precipitation are similar to observations (from 1990 to 2000), and are mainly obtained with the newer BC estimates.
\end{abstract}

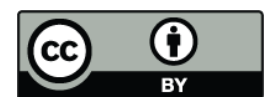

Correspondence to: $\mathrm{S}$. Menon (smenon@lbl.gov)

\section{Introduction}

India is a rapidly growing economy with GDP growth at $\$ 3$ trillion ( 1 trillion $=10^{12}$ ) in PPP for 2007 and with strong future growth potential. To meet economic demands, power-generation capacity has to increase sixfold by 2030 (Economist, 2008). Indian $\mathrm{CO}_{2}$ emissions have been rising steadily; and India also has the world's fourth biggest coal reserve. As expected emissions of greenhouse gases (GHGs) and particulate matter or aerosols have been increasing over the last few decades and are expected to increase in the future as well due to rapid industrial growth and slower emission control measures.

Black carbon (BC) aerosols are thought to affect the hydrology and radiative forcing over Asia (Ramanathan and Carmichael, 2008; Menon et al., 2002) as well as increase snow melt in snow covered regions (Jacobson, 2004; Hansen and Nazarenko, 2004; Flanner et al., 2007; Koch et al., 2009a). A recent study has suggested that $915 \mathrm{~km}^{2}$ of Himalayan glaciers in Spiti/Lahaul $\left(30-33^{\circ} \mathrm{N}, 76-79^{\circ} \mathrm{E}\right)$ thinned by an annual average of $0.85 \mathrm{~m}$ between 1999 to 2004 (Etienne et al., 2007) and observed records of snow cover trends in this region have indicated a sharp decline of 4\% from 1997 to 2003 (Goes et al., 2005). Himalayan ice core records indicate a significant amount of BC deposition in the Everest region for 1951 to 2000 with strong increases in BC since 1990 (Ming et al., 2008b) and data from the Atmospheric Brown Cloud project (Ramanathan et al., 2005, 2007) was used to suggest that the melting of the Himalayan glaciers is related to enhanced heating from $\mathrm{BC}$ aerosols and GHGs of $0.25 \mathrm{~K}$ per decade, from 1950 to present (similar to observations), of which the $\mathrm{BC}$ associated heating is $0.12 \mathrm{~K}$ per decade. Observations from five

Published by Copernicus Publications on behalf of the European Geosciences Union. 
stations in India also suggest a reduction in global surface radiation of $25 \mathrm{Wm}^{-2}$ over 43 years from 1964, with an annual rate of $-0.5 \mathrm{Wm}^{-2} \mathrm{a}^{-1}$ followed by a strong decrease of $-1.1 \mathrm{Wm}^{-2} \mathrm{a}^{-1}$ after 1990 (Ohmura, 2009).

Although BC-related climate impacts over the Indian subcontinental region are expected to be strong since 1990 no direct quantification of $\mathrm{BC}$ impacts on snow cover change have been estimated. Here, we show changes to snow/ice cover and precipitation (two critical components for the population/economy), due to aerosols for 1990 to 2010 for the Indian subcontinental region. We use the NASA Goddard Institute for Space Studies climate model (ModelE) coupled to an on-line aerosol chemistry/transport model and include the impacts from the aerosol direct (D) effect (scattering or absorption of radiation by aerosols), aerosol indirect (I) effect (changes to cloud properties and radiation due to aerosols) and changes to snow/ice albedo from BC deposition on snow/ice surfaces (SA). To understand how climate may vary based on changes in emissions for particular decades and from differences in emission inventories used, we examine various simulations. Anthropogenic aerosols included are sulfates and carbonaceous aerosols (organic matter and BC). For carbonaceous aerosols, we use the Bond (Bond et al., 2004) emissions but also include more recent emissions from India (Sahu et al., 2008) (referred to as Beig emissions) that differ from the Bond emissions for the Indian region $\left(7.5-37.5^{\circ} \mathrm{N}, 67.5-97.5^{\circ} \mathrm{E}\right)$ mainly for contributions to BC from coal, transportation and to some extent biofuel sources that are high in India (Venkataraman et al., 2005). Details of the various simulations performed are described in the next section and results are presented in Sect. 3. Conclusions from the study are in Sect. 4.

\section{Method}

The climate model, ModelE $\left(4^{\circ} \times 5^{\circ}\right.$ horizontal resolution and 20 vertical layers, timestep of 30 minutes) (Schmidt et al., 2006) is coupled with the aerosol chemistry/transport model of Koch et al. (2007) that includes sulfate chemistry and source terms for organic matter and $\mathrm{BC}$ aerosols that are transported and subject to the same physical processes (wet/dry deposition) as sulfates. Although the model has coarse resolution, the effective resolution for tracer transport is significantly greater than the nominal resolution due to the nine higher-order moments that are carried along with the mean tracer values in the grid box (Schmidt et al., 2006). Tracer mass, humidity and heat are transported using the quadrature upstream scheme. Size fractionated dust and seasalt are included but their anthropogenic fraction is assumed to be zero due to uncertainty in determining their anthropogenic burden. In our simulations they are treated as natural aerosols. The model assumes external mixtures for aerosols, and thus might underestimate the absorption properties of aerosols when they are internally mixed. For the Indian re- gion $\mathrm{BC}$ tends to be internally mixed with sulfates and seasalt and due to the external mixtures assumed in the model, we most likely underestimate BC absorption (Spencer et al., 2008).

ModelE includes both stratiform and convective clouds with a prognostic treatment for stratiform cloud water based on Del Genio et al. (1996, 2005). We also include schemes to treat aerosol-cloud interactions (Intergovernmental Panel on Climate Change, 2007) wherein an increase in aerosols increases cloud droplet number concentration (CDNC), reduces cloud droplet sizes that also inhibits precipitation, increasing cloud liquid water path and optical depth, cloud cover and hence cloud reflectivity. Although the treatment of the indirect effect is described earlier (Menon et al., 2008a), differences included here are: (1) a prognostic equation to calculate CDNC (Morrison and Gettelman, 2008) that includes both sources (newly nucleated CDNC that is a function of aerosol concentration and cloud-scale turbulence Lohmann et al., 2007) and sinks (CDNC loss from rainfall, contact and immersion freezing); (2) ice crystal concentrations obtained through both heterogeneous freezing via immersion and nucleation by deposition/condensation freezing (Morrison and Gettelman, 2008). Aerosols do not directly affect ice crystal nucleation due to considerable uncertainty in determining this relationship.

The aerosol direct effect is estimated from the difference between the TOA radiative flux with and without the aerosols, at each model time step and are then averaged over the year. The aerosol indirect effect is obtained from the change in net (shortwave + longwave) cloud radiative forcing. Both aerosol direct and indirect effects have been extensively evaluated in prior work (Koch et al., 2007; Menon et al., 2008a). To represent BC deposition on snow/ice surfaces and modifications to snow/ice albedo, BC concentrations in the top layer of snow (land and sea ice) are used to calculate the albedo reduction on snow grains with sizes varying from 0.1 to $1 \mathrm{~mm}$ (Koch et al., 2009a). The forcing is the difference between the instantaneous TOA radiative flux with and without the BC impact on snow/ice albedo. Sulfur and biomass (for sulfates and carbonaceous aerosols) emissions are from the Emission database for Global Atmospheric Research (V3.2 1995) and the Global Fire Emissions Database (v1), respectively (Koch et al., 2009a). Model simulations are run for 63 months and averaged for the last five years.

We perform several sets of simulations for the year 1990 and 2000 for each of the Beig and Bond emissions for those particular years. All simulations use climatological (monthly varying) observed sea-surface temperatures (SSTs) obtained from the Hadley Center sea ice and SST data version 1 (HadISST1) (Rayner et al., 2003). We use SST's for 19751984 as was previously evaluated for ModelE as in Schmidt et al. (2006), except if noted otherwise. GHG concentrations for all simulations are set to Year 1990 values except if noted otherwise. The simulations performed are shown 
Table 1. Description of simulations used for the study. All simulations are performed with the Beig and Bond emissions separately, unless indicated otherwise.

\begin{tabular}{lccccc}
\hline Simulation & Direct Effect & Indirect Effect & BC Snow Albedo Effect & Sea surface temperature & Greenhouse gases \\
\hline D & Yes & Fixed & No & $1975-1984$ & 1990 \\
D+I & Yes & Yes & No & $1975-1984$ & 1990 \\
NBC(D+I) & Yes & Yes & No & $1975-1984$ & 1990 \\
(Without black carbon) & & & & & $1975-1984$ \\
D+I+SA & Yes & Yes & Yes & $1993-2002$ & 1990 \\
(D+I+SA) & Yes & Yes & Yes & $1993-2002$ & 2000 \\
$($ D+I+SA) + GHG & Yes & Yes & Yes & & \\
\hline
\end{tabular}

in Tabl1 and are briefly described as follows: (1) The direct effect (D) only simulations use fixed cloud droplet number concentration for the oceans and land $\left(60\right.$ and $175 \mathrm{~cm}^{-3}$, respectively) and aerosols do not interact with cloud properties except through their radiative effects. (2) For the direct+indirect (D+I) effect simulations, aerosols interact with cloud properties by changing the cloud droplet number concentration and through the autoconversion scheme (that is a function of cloud droplet number concentration and the liquid water in the cloud Beheng, 1994). (3) We also perform simulations that include the snow/ice albedo (SA) change due to black carbon (BC) deposition on snow/ice surfaces (D+I+SA). (4) To evaluate the influence of sea-surface temperature (SST) changes on snow/ice cover, we include SSTs averaged for 1993-2002 for Year 2000 aerosol emissions instead of the 1975-1984 used for the (D+I+SA) simulations (referred to as $\left.(\mathrm{D}+\mathrm{I}+\mathrm{SA})_{\mathrm{C}}\right)$. This results in an average increase of $0.19^{\circ} \mathrm{C}$ in surface temperatures probably driven by GHG changes among other climate influences. (5) To isolate the role of black carbon, we remove BC for both Year 1990 and 2000 aerosol emissions for the (D+I+SA) simulation (referred to as $\mathrm{NBC}(\mathrm{D}+\mathrm{I})$ ). This simulation does not include BC effect on snow albedo since BC is essentially removed here. (6) Although the $(\mathrm{D}+\mathrm{I}+\mathrm{SA})_{\mathrm{C}}$ simulation may be considered as a proxy for the climate influence that includes the warming due to GHG changes for the decade (1993-2002 versus 1975-1984), we perform simulations with GHG concentrations set for the Year 2000 instead of 1990 for the Year 2000 aerosol emissions (referred to as $(\mathrm{D}+\mathrm{I}+\mathrm{SA})_{\mathrm{C}+\mathrm{GHG}}$ ) as a sensitivity test.

The sets of simulations described in Table 1 are performed for each of the Beig and Bond emissions except for Simulation $\mathrm{NBC}(\mathrm{D}+\mathrm{I})$, since the Beig and Bond emissions only differ in the amount of anthropogenic black carbon. Model internal variability may affect the robustness of the results for short runs (five years) and thus we compared results between a five year run and a 12 year run for simulation $(\mathrm{D}+\mathrm{I})$ with the Beig emissions. We note small differences of less than $2 \%$ for mean values of diagnostics of interest. However, despite small differences between the mean values for short and longer runs, we do acknowledge that some of the result- ing differences may be from random changes in simulated patterns and may also be model dependent. Statistical significance of differences for the main variables of interest are shown (snow/ice cover and precipitation) so that only meaningful results are evaluated. The interannual standard deviation is calculated as $(2 / \mathrm{n})^{1 / 2} \times \mathrm{SD}_{p}$, where $\mathrm{n}$ is the number of years in the simulation and $\mathrm{SD}_{p}$ is the pooled standard deviation as in Jones et al. (2007).

\section{Aerosol-climate effects}

Here, we examine aerosol distribution over India for the last decade, different effects of aerosols on radiation, snow/ice cover and precipitation, including future climate effects.

\subsection{Aerosol mass distribution}

Annual surface distributions for sulfates, organic matter, BC from fossil/bio-fuel and biomass sources for the Beig emissions for 2000 indicate high concentrations (Fig. 1) with average values of $2.03 \mu \mathrm{g} \mathrm{m}^{-3}$ for BC from fossil/bio-fuel over India ( $4^{\circ}$ to $40^{\circ} \mathrm{N}$ and $65^{\circ}$ to $105^{\circ} \mathrm{E}$ ) versus $1.05 \mu \mathrm{g} \mathrm{m}^{-3}$ for the Bond emissions. Compared to emissions for 1990, fossil/bio-fuel BC decreases over Europe and North America but increases over Asia (notably over China, India and the Middle East), similar to changes obtained for sulfates. Note that although only the $\mathrm{BC}$ emissions from fossil/biofuel sources are different between the simulations used here, small differences in aerosol concentrations do occur, most notably for sulfate. These are due to feedbacks to aerosols (especially for the sulfur chemistry cycle) from the various physical processes represented (wet scavenging, radiative heating from $\mathrm{BC}$ aerosols, dry deposition, etc.) and associated cloud changes. Comparison of simulated aerosols with aerosol observations over India are difficult since observations are at a few locations, are episodic and do not necessarily include all species of aerosols. However, where available, comparison of simulated $\mathrm{BC}$ aerosol with measurements (Table 2) over eight locations in India indicates that the model underestimates BC in general (especially the Bond emissions), though the spatial and seasonal distribution 

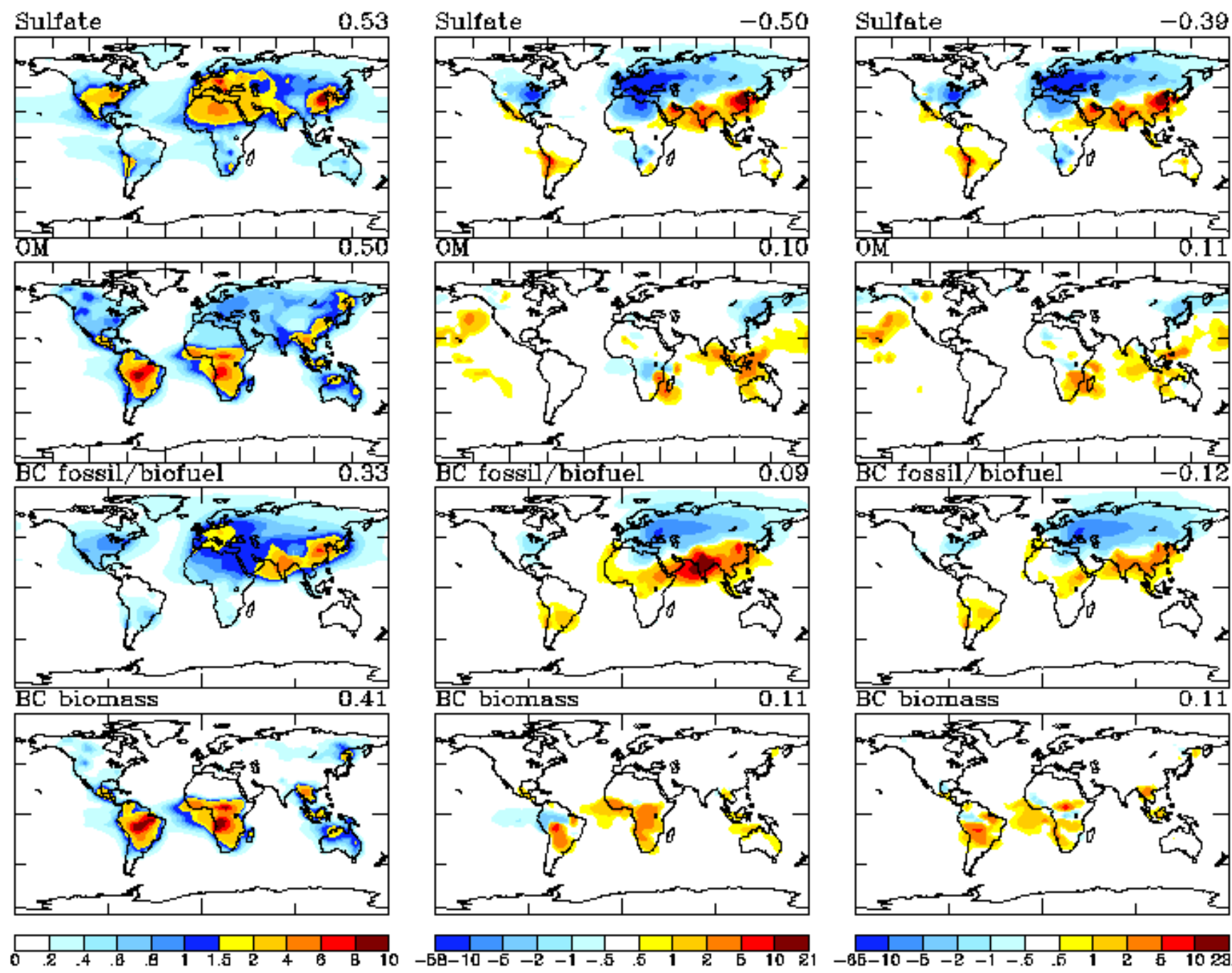

Fig. 1. Average annual surface layer mass concentrations $\left(\mu \mathrm{g} \mathrm{m}^{-3}\right)$ for sulfate and organic matter (OM) from all sources and black carbon (BC) from fossil/bio-fuel and biomass sources for the Beig emissions for 2000 (left panel). Differences between simulations from 1990 to 2000 are shown for the Beig (middle panel) and Bond (right panel) emissions. Values for BC are multiplied by a factor of 10 to facilitate comparison with other aerosols. Global values are listed on the rhs.

Table 2. Average mass of back carbon aerosols (in $\mu \mathrm{g} \mathrm{m}^{-3}$ ) from observations at eight locations in India (Beegum et al., 2009) for the different months and as simulated by the model for the Beig and Bond emissions for Year 2000.

\begin{tabular}{lrrrrrr}
\hline Location & $\begin{array}{r}\text { Observation } \\
\text { Jan-Feb }\end{array}$ & Beig & Bond & $\begin{array}{r}\text { Observation } \\
\text { Mar-May }\end{array}$ & Beig & Bond \\
\hline Minicoy & 0.47 & 0.13 & 0.08 & $0.06-0.22$ & 0.03 & 0.02 \\
Trivandrum & $5.2-5.7$ & 0.12 & 0.09 & $1.8-3.0$ & 0.05 & 0.04 \\
Port Blair & 2.6 & 0.22 & 0.22 & $2.7-6.9$ & 0.15 & 0.14 \\
Hyderabad & $21-25$ & 6.3 & 2.6 & $12-15$ & 2.4 & 0.85 \\
Pune & $6.4-7.3$ & 2.4 & 0.64 & $2.2-4.5$ & 1.2 & 0.30 \\
Kharagpur & $7.5-8.3$ & 7.27 & 3.2 & $2.7-6.9$ & 1.6 & 0.74 \\
Delhi & $19-27$ & 2.1 & 0.47 & $8-12$ & 2.2 & 0.57 \\
Nainital & $0.67-1.87$ & 0.34 & 0.10 & $1.3-1.6$ & 0.52 & 0.17 \\
\hline
\end{tabular}


Table 3. Annual average instantaneous shortwave radiative forcings at the top of the atmosphere averaged over India $\left(4^{\circ}-40^{\circ} \mathrm{N}\right.$ and $65^{\circ}-$ $105^{\circ} \mathrm{E}$ ) for the various simulations. OM refers to organic matter, BCB to black carbon from biomass sources and BCF to black carbon from fossil/bio-fuel sources. Global values are given in parenthesis since emission changes from 1990 to 2000 occur globally. Also included are values for the aerosol indirect effect (estimated from changes to the net (shortwave + longwave) cloud forcing), cloud liquid water path and cloud cover. All units are in $\mathrm{Wm}^{-2}$ unless otherwise indicated. Simulations represented include those with the Beig and Bond emissions for Year 2000 and changes (represented by $\Delta$ ) from differences in emissions from 1990 to 2000 (E).

\begin{tabular}{lrrrr}
\hline Species & Beig Year 2000 & Bond Year 2000 & $\Delta$ Beig E & $\Delta$ Bond E \\
\hline Sulfate & $-1.12(-0.86)$ & $-1.11(-0.86)$ & $-0.13(0.04)$ & $-0.15(0.03)$ \\
OM & $-1.19(-0.47)$ & $-1.19(-0.46)$ & $-0.11(-0.02)$ & $-0.11(-0.02)$ \\
BCB & $0.084(0.14)$ & $0.085(0.14)$ & $0.003(0.008)$ & $0.004(0.009)$ \\
BCF & $1.29(0.31)$ & $0.76(0.27)$ & $0.36(0.03)$ & $0.10(0.005)$ \\
Aerosol direct effect & $-0.94(-0.88)$ & $-1.46(-0.91)$ & $0.12(0.06)$ & $-0.16(0.02)$ \\
Liquid water path $\left(\mathrm{gm}^{-2}\right)$ & $43.33(47.88)$ & $44.78(48.05)$ & $0.02(0.056)$ & $0.46(0.22)$ \\
Cloud cover $(\%)$ & $50.51(57.42)$ & $51.33(57.43)$ & $-0.60(0.02)$ & $0.44(0.48)$ \\
Aerosol indirect effect & $-13.9(-16.6)$ & $-14.7(-16.7)$ & $0.10(-0.10)$ & $-0.30(-0.11)$ \\
Total aerosol effect & $-14.8(-17.5)$ & $-16.2(-17.6)$ & $0.22(-0.04)$ & $-0.46(-0.09)$ \\
\hline
\end{tabular}

Table 4. Annual average differences in TOA net radiation (NR-TOA), surface net radiation (NR-Sfc), atmospheric forcing, snow/ice cover, precipitation and low cloud cover for the Indian region $\left(4^{\circ}-40^{\circ} \mathrm{N}\right.$ and $\left.65^{\circ}-105^{\circ} \mathrm{E}\right)$ for the Beig and Bond emissions with $\Delta$ denoting differences between simulations for changes from 1990 to 2000 for changing emissions (E) and changes from climate (C). Simulations represented include the direct and indirect effects.

\begin{tabular}{lrrrr}
\hline Variable & $\Delta$ Beig E & $\Delta$ Bond E & $\Delta$ Beig C & $\Delta$ Bond C \\
\hline NR-TOA $\left(\mathrm{Wm}^{-2}\right)$ & 0.14 & -0.42 & -1.31 & -1.74 \\
NR-Sfc $\left(\mathrm{Wm}^{-2}\right)$ & -1.11 & -1.22 & -0.51 & 0.22 \\
Atmospheric forcing $\left(\mathrm{Wm}^{-2}\right)$ & 1.25 & 0.80 & -0.80 & -1.96 \\
Snow/ice cover $(\%)$ & -0.46 & 0.46 & 0.33 & 0.54 \\
Precipitation (mm/day) & -0.08 & 0.05 & 0.08 & -0.01 \\
Low cloud cover $(\%)$ & -0.28 & 0.22 & -0.03 & 0.63 \\
\hline
\end{tabular}

are reasonably well simulated. Differences between model and observations are larger than are differences due to the two emission inventories used. Some of the reasons for the model underestimation may be attributed to the comparison between values obtained from a coarse resolution model versus measurements that were mostly from urban areas; under estimation of aerosol emissions from the source, treatment of physical processes for aerosol advection and transport as indicated in Koch et al. (2009b). These are hard to resolve without more measurements that could help evaluate model representation more carefully.

Additional comparison of aerosol optical depth (AOD) when fine mode aerosol particles (sulfates, carbonaceous aerosols) dominate during November to January over Kanpur, India (Jethva et al., 2005) indicates that compared to the observed AOD of 0.4-0.7, simulated AOD for the Beig/Bond emissions are 0.14/0.08; and compared to the observed absorption AOD of 0.05-0.06, simulated absorption AOD for the Beig/Bond emissions are 0.06/0.01. Although with the Beig emissions the model under-predicts the $\mathrm{BC}$ aerosol mass and AOD by a factor of 3 compared to observations, the absorption AOD is similar. The absorption AOD is indicative of the amount of aerosols that are absorbing. However, since the model underpredicts the AOD, the single scattering albedo is overestimated. The under-estimation of simulated optical properties w.r.t. observations for the Bond emissions are larger and thus the Beig emissions represents to a somewhat better extent the aerosol distribution over India.

\subsection{Aerosol direct and indirect effects}

The radiative forcing associated with aerosols is usually negative, except if they absorb solar radiation. Since BC aerosols are absorbing, the increased fossil/bio-fuel BC from the Beig emissions (46\% from 1990 to 2000 versus 14\% increase for the Bond emissions) results in a higher value for the aerosol direct effect $\left(0.36 \mathrm{Wm}^{-2}\right.$ versus $0.10 \mathrm{Wm}^{-2}$ for the Bond emissions). This results in a higher total direct aerosol effect for the Beig emissions $\left(0.12 \mathrm{Wm}^{-2}\right)$ compared to that obtained for the Bond emissions $\left(-0.16 \mathrm{Wm}^{-2}\right)$ (Table 3$)$. Although the aerosol indirect effect is usually negative (Intergovernmental Panel on Climate Change, 2007), we obtain values of $0.10 /-0.30 \mathrm{Wm}^{-2}$ for the Beig/Bond emissions 

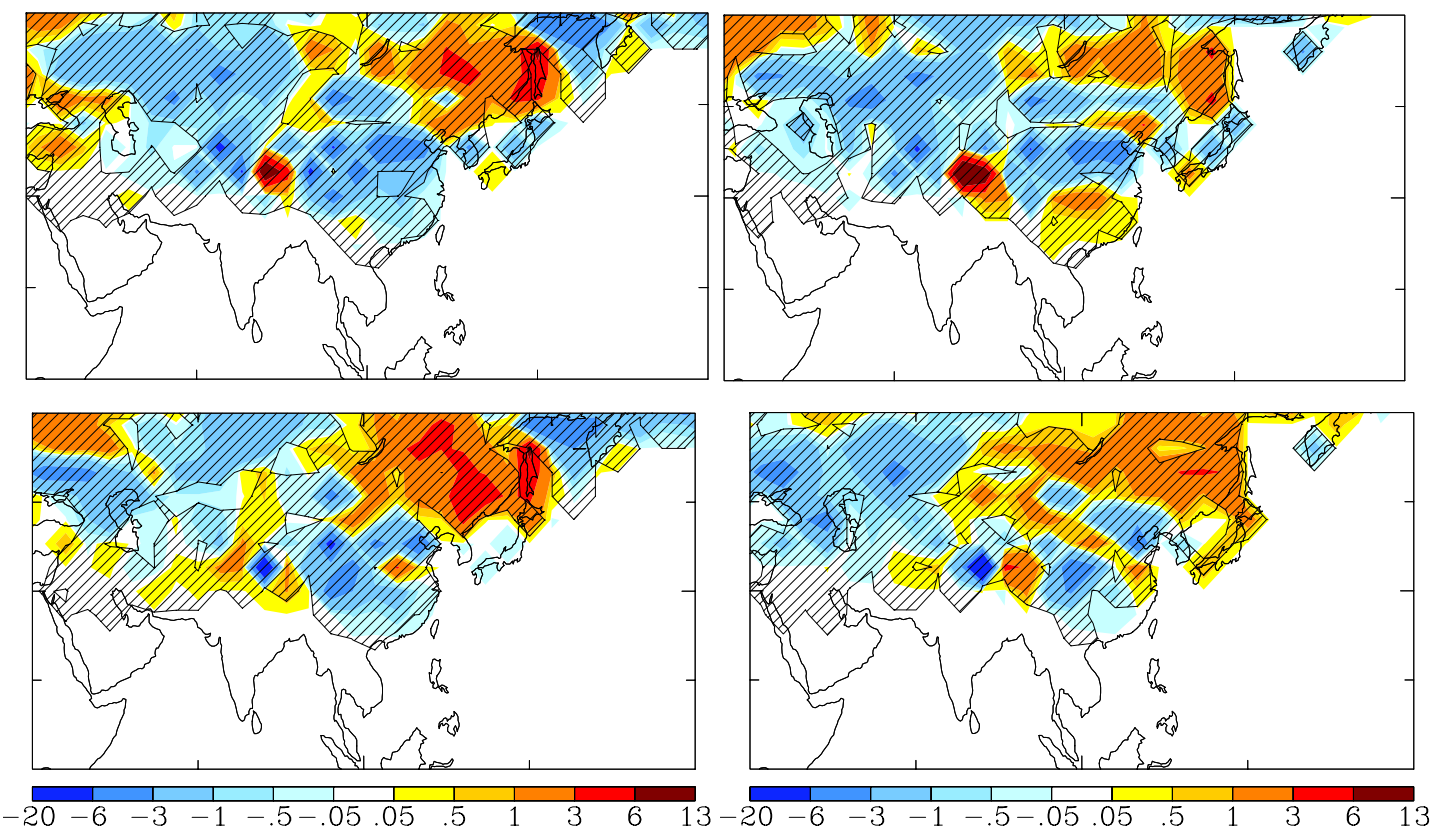

Fig. 2. Average difference in annual snow/ice cover (\%) for differences in emissions between 2000 and 1990 with (left panel) and without (right panel) the climate influence for the Beig (top panels) and Bond (bottom panels) emissions. Simulations include the direct and indirect effects and changes in snow/ice albedo due to black carbon deposition on snow/ice surfaces. Differences that are significant at the $95 \%$ confidence level are indicated by hatched areas.

over India due to emission changes from 1990 to 2000. The positive value of the indirect effect for the Beig emissions comes from near neutral changes to cloud liquid water path and a decrease in total cloud cover (Table 3). Usually, for negative indirect effects these variables (cloud cover and liquid water path) increase. Thus, the reduction in clouds and liquid water path (similar to the semi-direct effect Ackerman et al., 2000; Menon, 2004) due to the heating effects of absorbing aerosols (fossil/bio-fuel BC) outweigh the impacts from the indirect effect. The positive aerosol forcings obtained with the enhanced India fossil/bio-fuel BC aerosols can have a strong impact on climate. For the rest of the discussion, we focus mainly on their heating effects over the Indian region.

Table 4 indicates simulated values for net radiation at the top-of-the-atmosphere (TOA) and the surface for simulations with the (D+I) effects. We also performed simulations $(D+I)_{C}$ shown in Table 4 that distinguishes between climate and emission changes for the (D+I) effects. TOA Net radiation change from 1990 to 2000 for the Beig emissions is positive (due to the enhanced fossil/bio-fuel BC) compared to the negative value obtained with the Bond emissions; and the surface net radiation is negative for both due to the overall aerosol load increases for both cases that reduces radiation that can reach the surface. The reduction in surface radiation and the positive forcing at TOA results in the high value of atmospheric forcing simulated for the Beig emissions that indicates stronger heating effects of fossil/bio-fuel $\mathrm{BC}$ over the column. This decreases cloud and snow/ice cover and precipitation is reduced compared to the changes obtained with the Bond emissions. However, for warmer temperatures (from the 1993-2002 SSTs) for the Year 2000 emissions, cloud cover decreases slightly (Beig emissions) or increases (Bond emissions) and TOA net radiation decreases (implying a more reflective atmosphere) and snow-cover increases due to the reduced atmospheric forcing.

\subsection{Snow/ice cover changes from black carbon aerosols}

With the additional positive forcing from $\mathrm{BC}$ deposition on snow/ice surfaces included (the (D+I+SA) simulation), precipitation and cloud cover actually decrease as does snow/ice cover for emission and climate changes from 1990 to 2000, as shown in Table 5. BC snow-albedo forcings are $0.03 /-0.02 \mathrm{Wm}^{-2}$ for Beig/Bond emission changes from 1990 to 2000 and with warmer temperatures (from the 1993$2002 \mathrm{SSTs}$ ), these values are $0.0 /-0.02 \mathrm{Wm}^{-2}$, respectively. With warmer temperatures, precipitation reduces further and results in less BC deposition on the surface and thus reduced snow albedo forcings. This is further confirmed by a small reduction in surface fossil/bio-fuel BC amounts for the simulations with changes in SSTs (simulation is referred to as $\left.(\mathrm{D}+\mathrm{I}+\mathrm{SA})_{\mathrm{C}}\right)$. Relevant changes to snow/ice cover for simulations with the $(\mathrm{D}+\mathrm{I}+\mathrm{SA})_{\mathrm{C}}$ effects, shown in Fig. 2 are a decline of 0.97/1.1 (\%) for the Beig/Bond emission changes for 
Table 5. Annual average differences in TOA net radiation (NR-TOA), surface net radiation (NR-Sfc), atmospheric forcing, snow/ice cover and low cloud cover for the Indian region $\left(4^{\circ}-40^{\circ} \mathrm{N}\right.$ and $\left.65^{\circ}-105^{\circ} \mathrm{E}\right)$ for the Beig emissions for differences between simulations for changes from 1990 to 2000 for the different simulations listed in Table 1.

\begin{tabular}{lrrrrrr}
\hline Variable & $\mathrm{D}$ & $\mathrm{D}+\mathrm{I}$ & $\mathrm{D}+\mathrm{I}+\mathrm{SA}$ & $(\mathrm{D}+\mathrm{I}+\mathrm{SA})_{\mathrm{C}}$ & $\mathrm{NBC}(\mathrm{D}+\mathrm{I})$ & $(\mathrm{D}+\mathrm{I}+\mathrm{SA})_{\mathrm{C}+\mathrm{GHG}}$ \\
\hline NR-TOA $\left(\mathrm{Wm}^{-2}\right)$ & -0.60 & 0.14 & -0.75 & -0.68 & -0.52 & -0.57 \\
NR-Sfc $\left(\mathrm{Wm}^{-2}\right)$ & -1.58 & -1.11 & -1.22 & -0.65 & -0.86 & 0.50 \\
Atmos. forcing $\left(\mathrm{Wm}^{-2}\right)$ & 0.98 & 1.25 & 1.97 & -0.03 & 0.34 & -1.07 \\
Snow/ice cover $\%)$ & 0.09 & -0.46 & -0.86 & -0.97 & -0.89 & -0.70 \\
Low cloud cover $(\%)$ & -0.02 & -0.28 & -0.31 & -0.65 & -0.68 & -0.46 \\
\hline
\end{tabular}
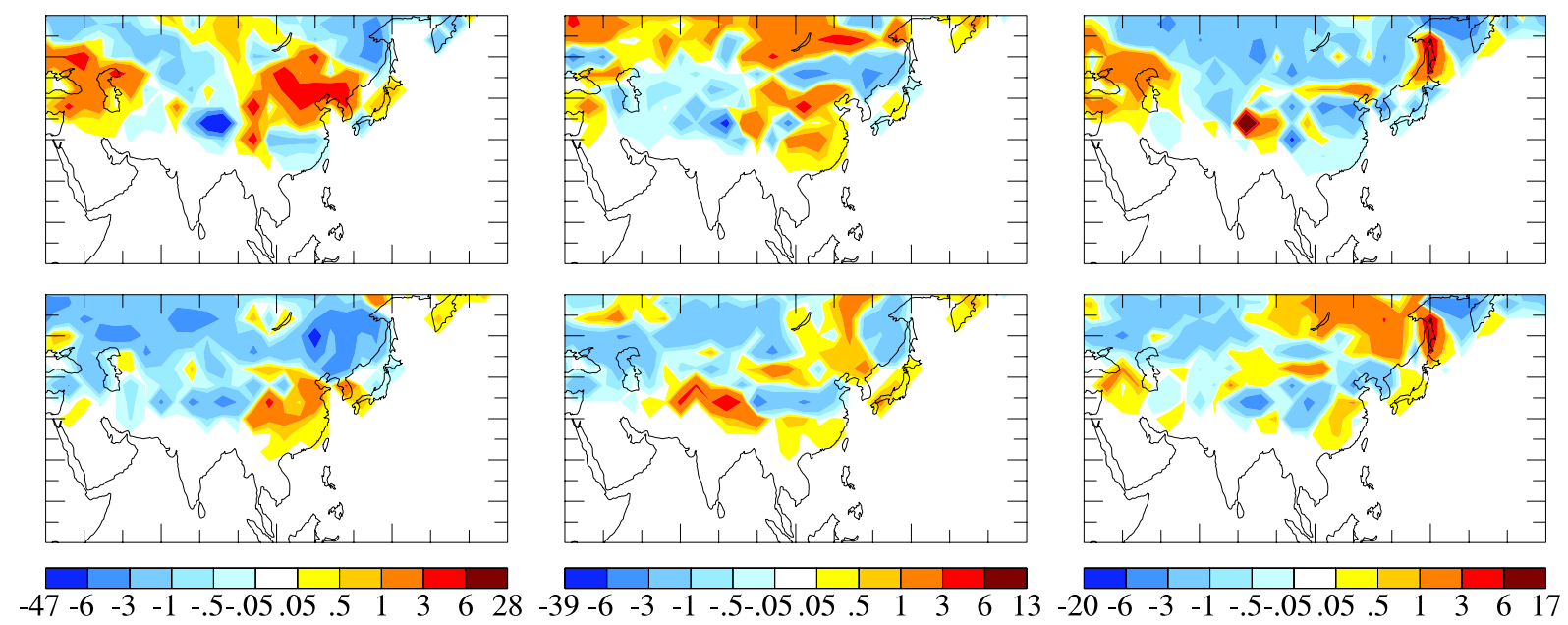

Fig. 3. Difference in annual average snow/ice cover for differences in emissions between 2000 and 1990 due to the direct effect (D) (left panels), direct+indirect effect (D+I) (middle panels) and D+I+snow albedo changes due to black carbon deposition (SA) along with seasurface temperature (SST) and GHG changes for Year 2000 emissions ((D+I+SA) + GHG $)$ (right panels) for the Beig (top panels) and Bond (bottom panels) emissions.

2000 compared to that obtained for 1990 (see also Tables 5 and 6). Without any climate driven influence (from warmer SSTs) corresponding values are $-0.86 /-0.63(\%)$, respectively (for the (D+I+SA) simulations). The aerosol contribution to the decline is $\sim 90 / 60 \%$ for the Beig/Bond emissions and we estimate that the contribution of the enhanced fossil/bio-fuel $\mathrm{BC}$ from the Beig emissions to the decrease in snow/ice cover is $36 \%$ (based on differences between the $0.86(\%)$ and $0.63(\%)$ snow/ice cover change obtained with the Beig versus Bond emissions).

Figure 3 indicates changes to snow/ice cover for simulations (D), (D+I) and $(\mathrm{D}+\mathrm{I}+\mathrm{SA})_{\mathrm{C}+\mathrm{GHG}}$ for the Beig and Bond emissions. Figure 4 shows similar changes for simulation $(\mathrm{NBC}(\mathrm{D}+\mathrm{I}))$. With BC removed, compared to results from simulation $(\mathrm{D}+\mathrm{I}+\mathrm{SA})$, overall there is a general decrease in snow/ice cover over much of the Himalayan region with an increase near $35-45^{\circ} \mathrm{N}$ and $75-100^{\circ} \mathrm{E}$, contrary to observations that are shown in Fig. 5. The change in snow/ice cover for simulation $\mathrm{NBC}(\mathrm{D}+\mathrm{I})$ is a decrease of $0.89 \%$ compared to the decrease of $0.86 \%$ obtained with the Beig emissions described earlier (Tables 5). Although the magnitude of the

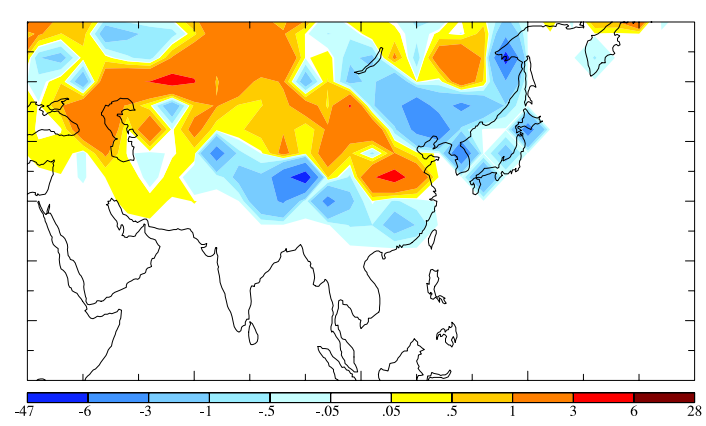

Fig. 4. Similar to Fig. 3 but for changes in annual average snow/ice cover for a simulation with (D+I) effects but without any anthropogenic black carbon for Year 1990 and 2000 emissions.

decrease without $\mathrm{BC}$ is comparable to that obtained with $\mathrm{BC}$, the spatial patterns of snow/ice cover changes without $\mathrm{BC}$ indicate a general decrease everywhere and are not comparable to observations that indicate an increase around $30^{\circ} \mathrm{N}$, $90-100^{\circ} \mathrm{E}$ and a decrease around it (Figs. 4 and 5). An 
Table 6. Similar to Table 5 but for the Bond emissions. Values for NBC(D+I) are not included since the Beig and Bond emissions only differ in the anthropogenic black carbon included.

\begin{tabular}{lrrrrr}
\hline Variable & $\mathrm{D}$ & $\mathrm{D}+\mathrm{I}$ & $\mathrm{D}+\mathrm{I}+\mathrm{SA}$ & $(\mathrm{D}+\mathrm{I}+\mathrm{SA})_{\mathrm{C}}$ & $(\mathrm{D}+\mathrm{I}+\mathrm{SA})_{\mathrm{C}+\mathrm{GHG}}$ \\
\hline NR-TOA $\left(\mathrm{Wm}^{-2}\right)$ & 0.58 & -0.42 & 0.41 & -0.46 & -0.99 \\
NR-Sfc $\left(\mathrm{Wm}^{-2}\right)$ & -1.25 & -1.22 & -1.51 & -0.34 & 0.93 \\
Atmospheric forcing $\left(\mathrm{Wm}^{-2}\right)$ & 1.83 & 0.80 & 1.92 & -0.12 & -0.06 \\
Snow/ice cover $\%)$ & -0.29 & 0.46 & -0.63 & -1.07 & -0.66 \\
Low cloud cover $(\%)$ & -0.27 & 0.22 & 0.18 & -0.01 & 0.33 \\
\hline
\end{tabular}

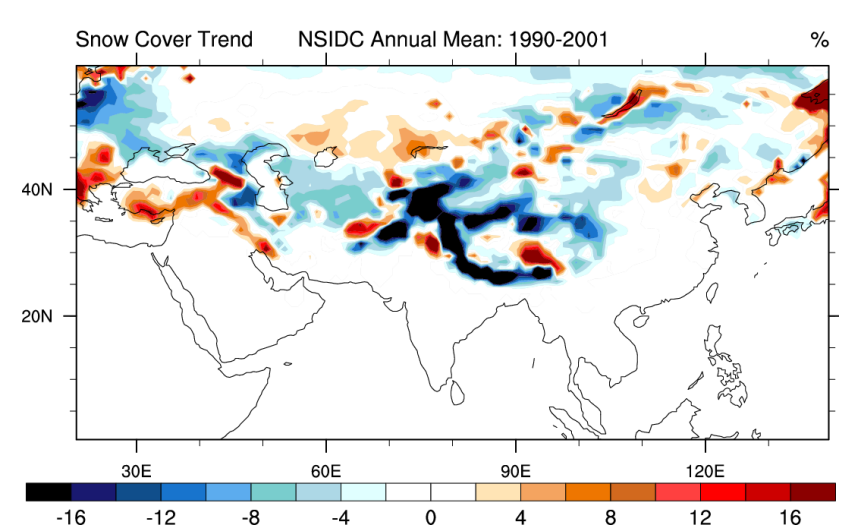

Fig. 5. Trend in annual linear snow cover (\% per decade) from 1990 to 2001 as obtained from the National Snow and Ice Data Center (NSIDC) EASE_Grid weekly snow cover and sea ice extent dataset (Armstrong and Brodzik, 2005). Trend is based on a least-square linear fit.

important point to note though is that the simulated decrease in snow/ice cover is greatly underestimated by the model compared to observations. From observed changes, the decline in snow/ice cover for the domain of interest $\left(4^{\circ}\right.$ to $40^{\circ} \mathrm{N}$ and $65^{\circ}$ to $105^{\circ} \mathrm{E}$ ) is $6.4 \%$ over the $1990-2001$ time period (or $5.33 \%$ decrease for a 10 year period). Some of the difference between the magnitude estimated from the simulations and that observed may be attributed to the general underestimation of BC amounts over India as indicated in Table 2, and also to physical processes represented (e.g. aerosol optical properties: with the external aerosol mixture assumed, the model could underestimate absorption efficiencies of internally mixed species).

The $(\mathrm{D}+\mathrm{I}+\mathrm{SA})_{\mathrm{C}}$ simulations do not directly account for GHG emission changes. Accounting for GHG emission changes for Year 2000 versus Year 1990 we find a decrease in snow/ice cover of 0.70/0.66 (\%) for the Beig/Bond emissions (Tables 5 and 6, Fig. 3) for simulation $\mathrm{D}+\mathrm{I}+\mathrm{SA})_{\mathrm{C}+\mathrm{GHG}}$. The decline is lower than without GHG changes $\left((\mathrm{D}+\mathrm{I}+\mathrm{SA})_{\mathrm{C}}\right)$ since the increase in snow/ice cover $\left(80-90^{\circ} \mathrm{E}\right)$ is stronger than in the other simulations (and also compared to observations). Simulation $\left((\mathrm{D}+\mathrm{I}+\mathrm{SA})_{\mathrm{C}+\mathrm{GHG}}\right)$ also reasonably depicts snow/ice cover decline but mainly for the Beig emis- sions. Overall, the spatial pattern of snow/ice cover decline is best captured by simulations $(\mathrm{D}+\mathrm{I}+\mathrm{SA})$ and $(\mathrm{D}+\mathrm{I}+\mathrm{SA})_{\mathrm{C}}$ and to some extent $\left.(\mathrm{D}+\mathrm{I}+\mathrm{SA})_{\mathrm{C}+\mathrm{GHG}}\right)$ for the Beig emissions although the magnitude simulated is lower than observed. However, compared with the simulations that use the Bond emissions, the simulations with the Beig emissions best represent observed changes.

A recent study (Flanner et al., 2009) also suggest that BC SA effects are important in simulating Eurasian springtime snow/ice cover changes and that the effects of carbonaceous aerosols are comparable to that of $\mathrm{CO}_{2}$ in causing the snow/ice cover decline. These results are also comparable to that found from simulations similar to the ones performed here with the same climate model but coupled with a Q-flux model (Koch et al., 2009a). Results from (Koch et al., 2009a) for pre-industrial to present-day emission changes indicate a decline of $0.6 \%$ for GHG and BC SA effects for the Indian sub-continental region.

In general, for changes driven by changing aerosol emissions only, with increased atmospheric forcing, snow/ice cover decrease. The spatial patterns of a simulated decrease in snow/ice cover above $25^{\circ} \mathrm{N}$ and an increase to the northeastern side, similar to observations (Fig. 5), is mainly obtained with the Beig emissions as shown in Fig. 2 (top left panel). This pattern also coincides with the BC snow-albedo forcings (Fig. 6), BC deposition flux, ground albedo and temperatures at $630 \mathrm{hPa}$ (Fig. 7). Although the snow/ice cover decline is slightly less than indicated in observations and the BC snow-albedo forcing is smaller than other modeling studies (Flanner et al., 2007; Ming et al., 2008b), qualitative features do indicate a BC impact on snow/ice cover that are similar to observations, obtained for the higher Indian fossil/biofuel BC emissions only.

To examine changes to snow/ice cover from $\mathrm{BC}$ aerosols for 2010, we use the Beig emission inventory for 2010 that has enhanced fossil/bio-fuel BC (51\%) compared to 2000. We call this "future change" since the most complete suite of emissions presently available for a global climate model are for Year 2000. To isolate the role of the enhanced Indian BC from the Beig emissions on snow/ice cover we examine differences between simulations that use the Beig and Bond emissions for 2000 to examine presentday changes; and for future changes we examine differences 


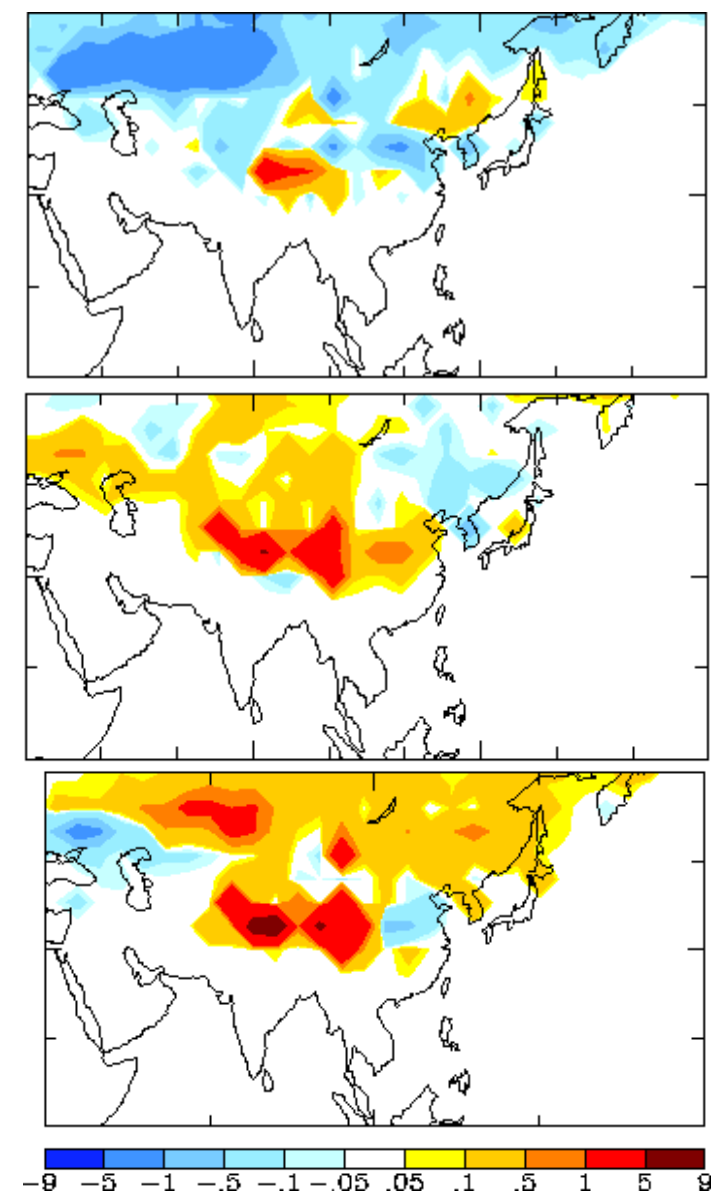

Fig. 6. Differences in annual average forcing $\left(0.1 \mathrm{Wm}^{-2}\right)$ from changes to snow/ice albedo due to black carbon (BC) deposition on snow/ice surfaces for simulations that also include the direct and indirect effects. The top panel represents the simulation with the Beig emission changes from 1990 to 2000 along with climate driven changes (from changes to sea-surface temperatures). The middle panel represents differences due to BC used in the Beig and Bond emissions for present-day (Year 2000) and the bottom panel represents future changes (from 2000 to 2010) from BC for the Beig emissions.

due to the Beig emissions from 2000 to 2010 (Fig. 8) (simulations represented include the $(\mathrm{D}+\mathrm{I}+\mathrm{SA})_{\mathrm{C}}$ effects). The model predicts that the geographic pattern of snow/ice cover change is reversed to some extent for the future. Despite the high BC snow-albedo forcings for the future over the entire Himalayan-Hindu-Kush region (Fig. 6), the temperature pattern (Fig. 7) is more consistent with the snow/ice cover changes indicating a stronger atmospheric heating influence from fossil/bio-fuel BC. These may be related to the spatial distribution of fossil/bio-fuel $\mathrm{BC}$ aerosols.

Higher concentrations of fossil/bio-fuel $\mathrm{BC}$ are located near eastern versus western India for the future versus for the Year 2000; and the prevailing winds that could transport air warmed by the absorbing fossil/bio-fuel BC aerosols (Fig. 9)

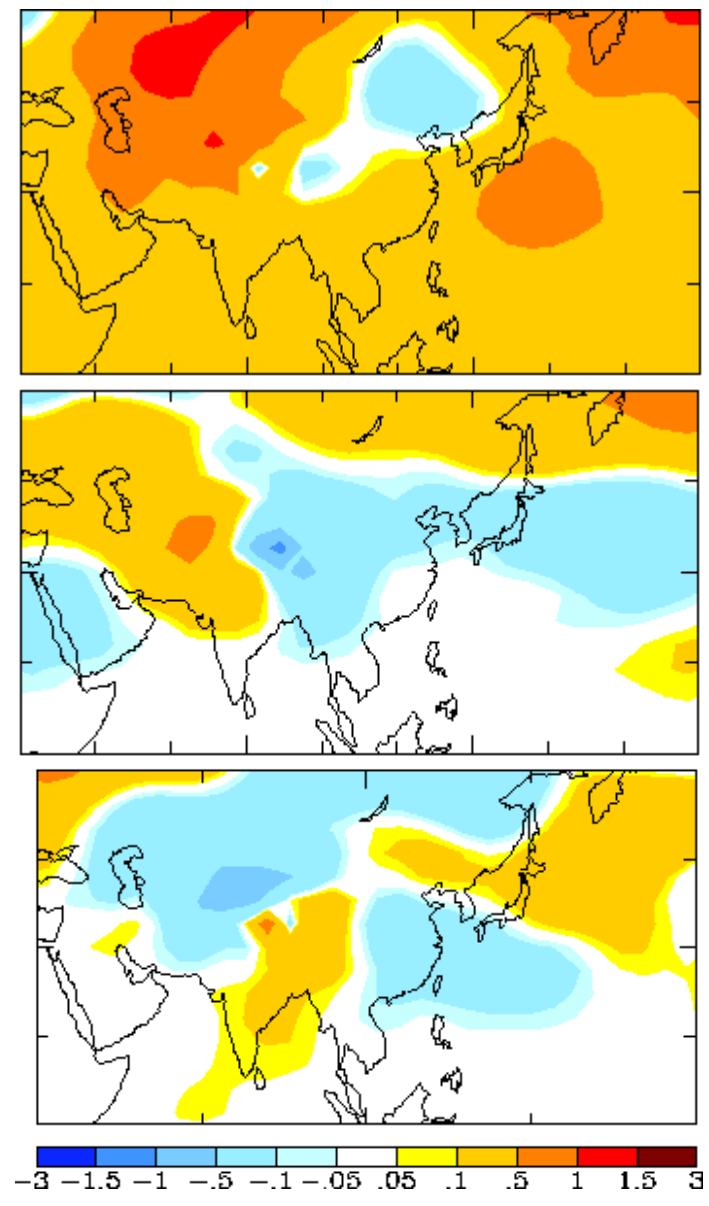

Fig. 7. Similar to Fig. 6 but for temperature at $630 \mathrm{hPa}$. We use temperatures at $630 \mathrm{hPa}(\sim 4000 \mathrm{~m})$ that are indicative of surface temperatures for the high mountain ranges in the Himalayan-HinduKush region that vary in height between 3 to $5 \mathrm{~km}$ (Ramanathan et al., 2007).

is more westerly for the future (and of opposite sign for the present-day case). The higher fossil/bio-fuel BC amounts for the future result in a decrease in snow/ice cover $(-0.05 \%)$ mainly from emission changes for Year 2010 and 2000, and with SST changes included (differences between Year 2010 emissions with 1993-2002 SSTs and Year 2000 emissions with 1974-1984 SSTs) snow/ice cover declines by $0.16 \%$. Thus, the contribution of fossil/bio-fuel BC to the decrease in snow/ice cover from 2000 to 2010 is $31 \%$ similar to the $36 \%$ contribution obtained from the enhanced Indian BC, from 1990 to 2000 , as stated earlier.

\subsection{Impacts of aerosols on precipitation}

In addition to snow/ice cover changes we also examine changes in the summer (June to August) precipitation due to fossil/bio-fuel BC aerosols (right panel of Fig. 8). We find an increase in summer precipitation for the eastern parts of India with a decline in most other areas from the increased 

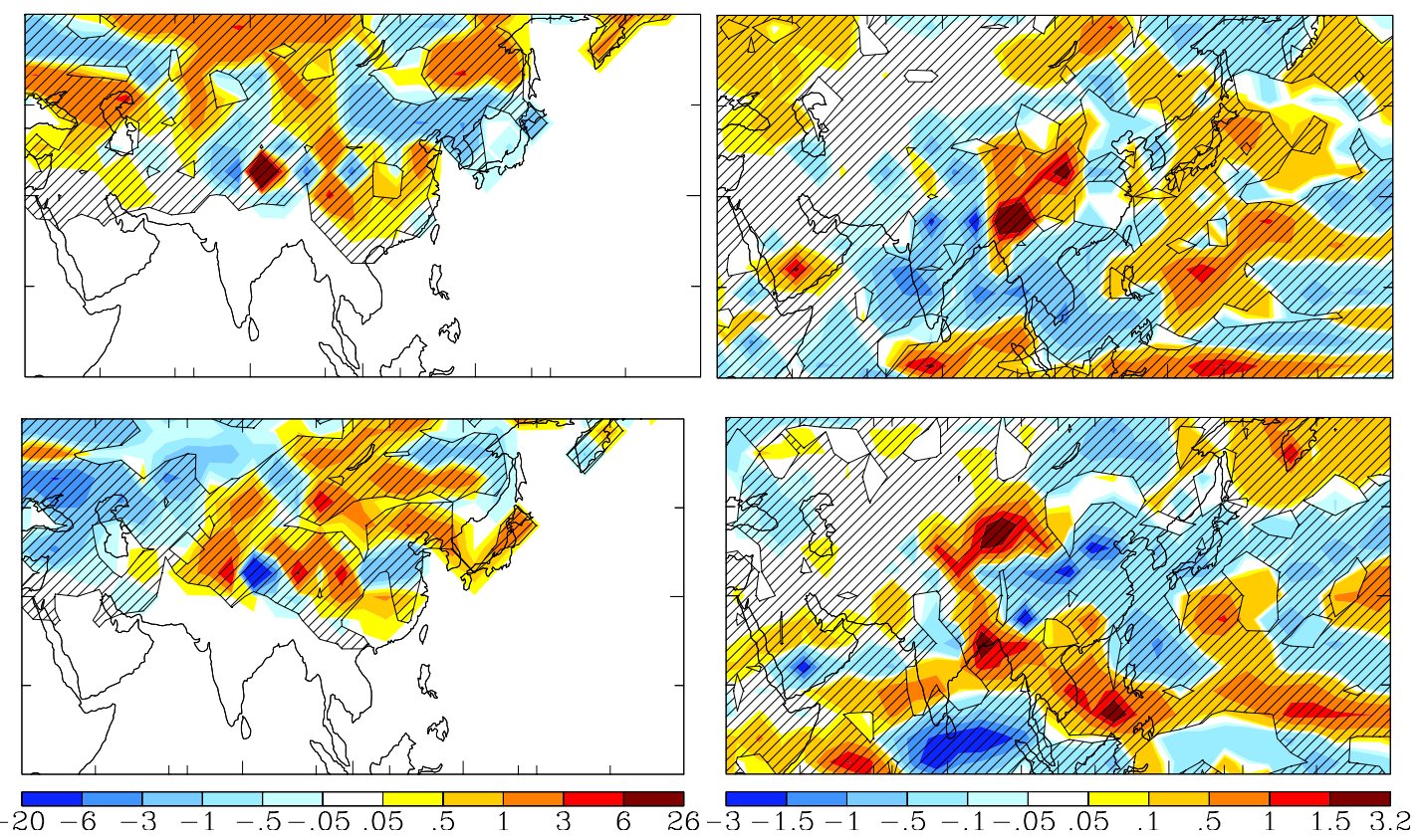

Fig. 8. Average difference in annual snow/ice cover (\%) (left panel) and June-July-August precipitation (mm/d) (right panel). The top panels represent differences due to black carbon used in the Beig and Bond emissions for present-day (Emissions from year 2000 are considered as present-day since these are the most current full suite of emission inventories available for the chemistry model). The bottom panels represent future changes (from 2000 to 2010) from black carbon for the Beig emissions. Simulations represented are $(\mathrm{D}+\mathrm{I}+\mathrm{SA})_{\mathrm{C}}$. Differences that are significant at the $95 \%$ confidence level are indicated by hatched areas.
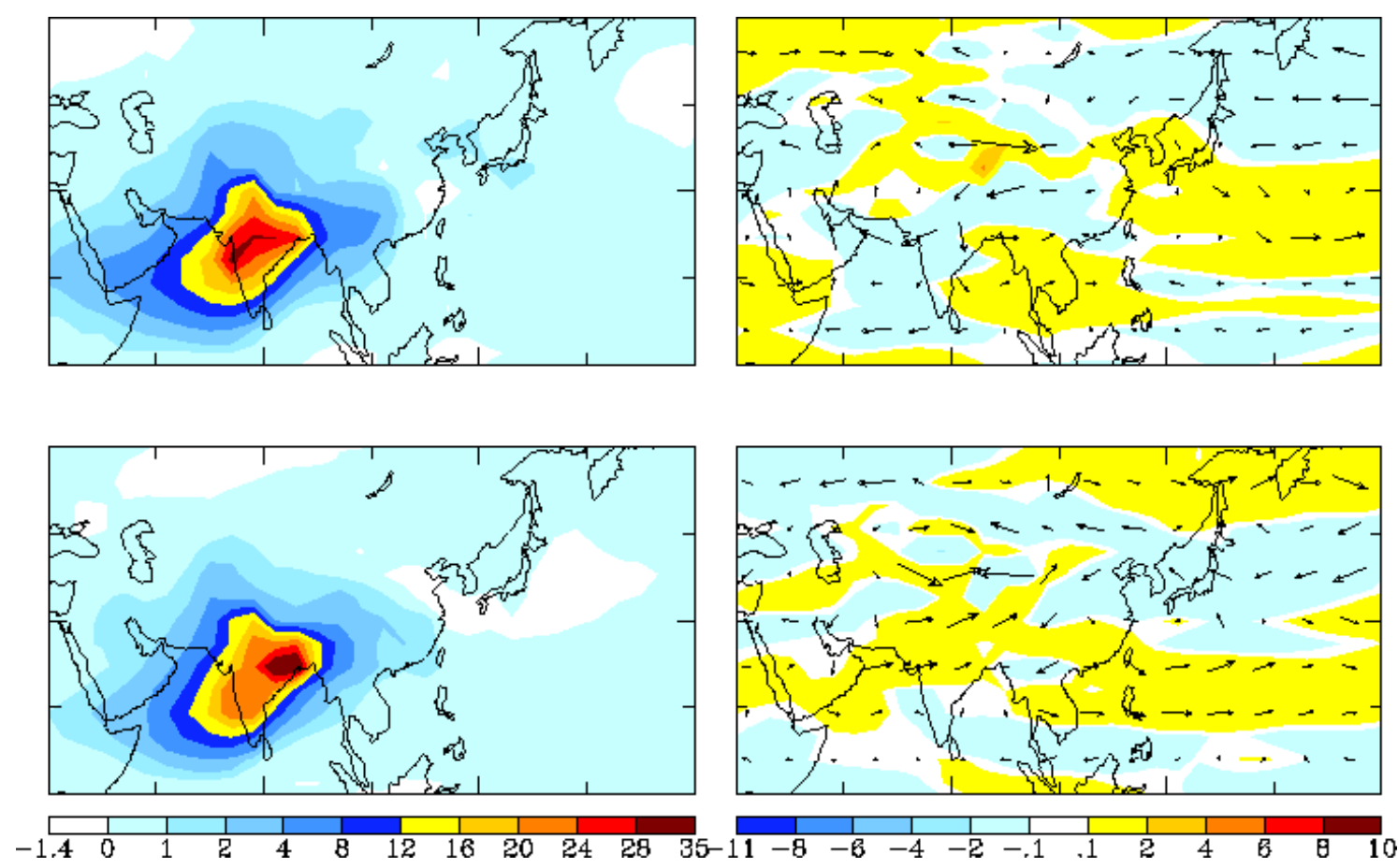

Fig. 9. Differences in annual average black carbon aerosols $\left(0.1 \mu \mathrm{g} \mathrm{m}^{-3}\right)$ from fossil and bio-fuel sources (left panel) and wind fields (ms $\left.{ }^{-1}\right)$ at $630 \mathrm{hPa}$ (right panel). The top panels represent differences due to black carbon used in the Beig and Bond emissions for present-day (Year 2000) and the bottom panels represent future changes (from 2000 to 2010) from black carbon for the Beig emissions. 

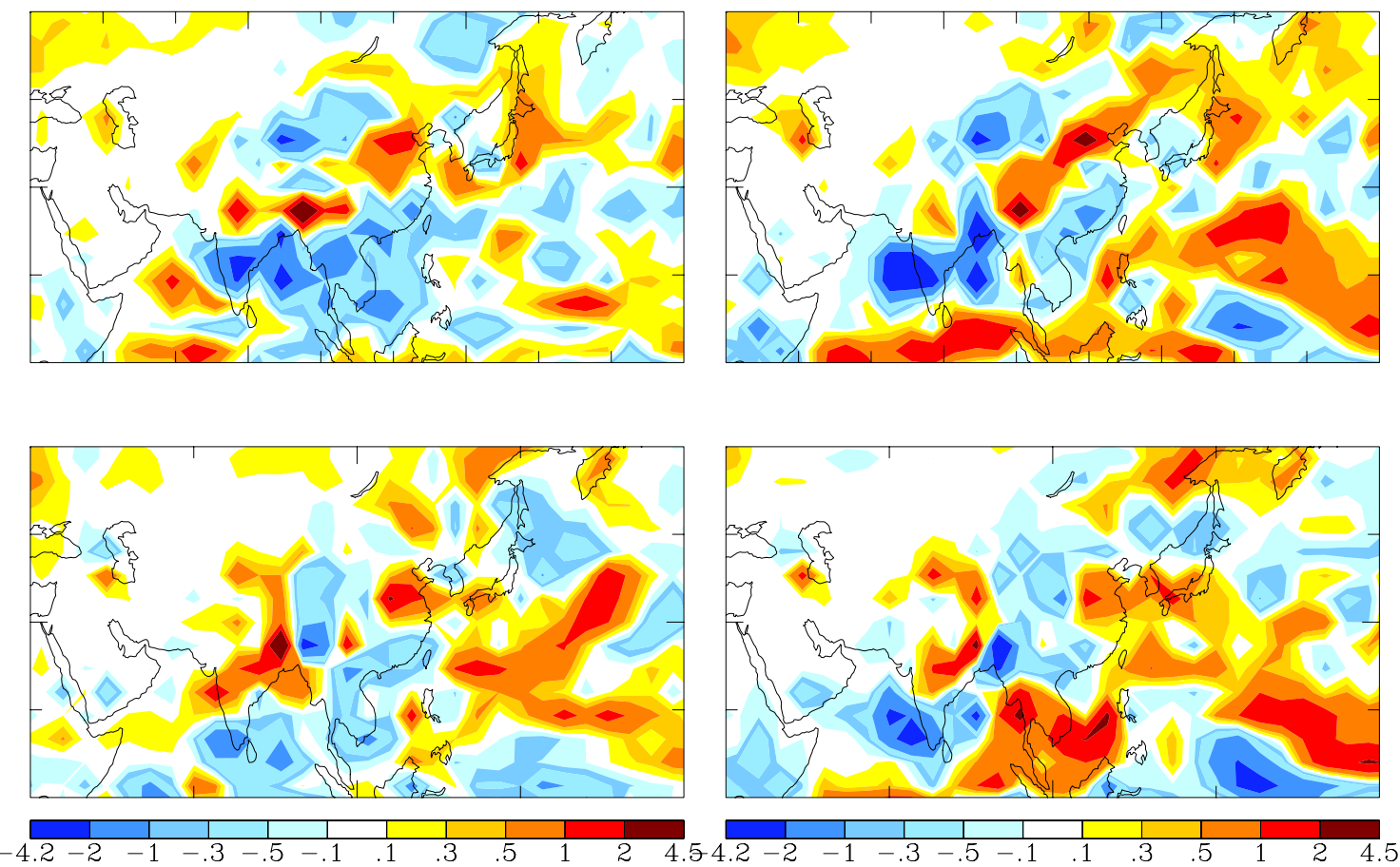

Fig. 10. Average difference in summer (June to August) precipitation (in mm/d) for differences in emissions between 2000 and 1990 without (left panel) and with (right panel) the climate influence for the Beig (top panels) and Bond (bottom panels) emissions. Simulations include the direct and indirect effects and changes in snow/ice albedo due to black carbon deposition on snow/ice surfaces.

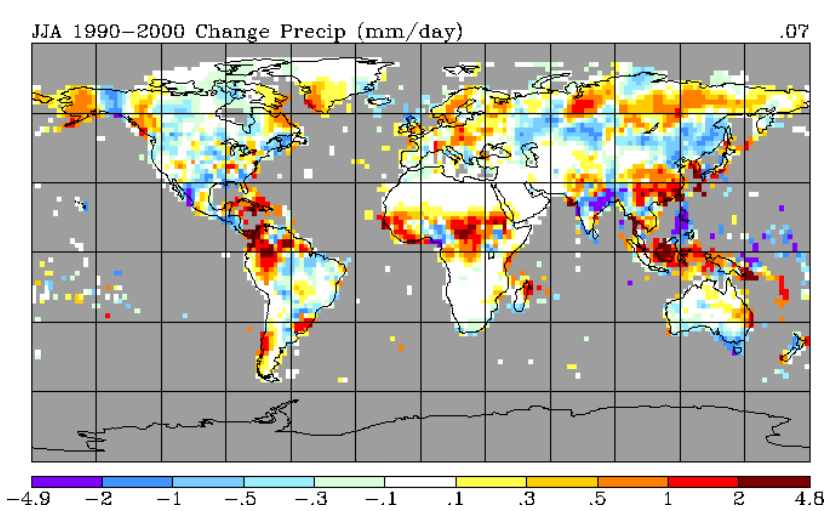

Fig. 11. Trend in summer (June to August (JJA)) precipitation from 1990 to 2000 using observations from CRU TS2.0 (Mitchell and Jones, 2005) available at http://data.giss.nasa.gov/precip_cru/maps. html. Global mean change is given on the r.h.s. of the figure.

fossil/bio-fuel BC emissions for 2000. For the future projection, with an increase in fossil/bio-fuel $\mathrm{BC}$ emissions the decrease is confined to the north-central (not statistically significant) and southern parts. With the Beig emissions precipitation changes over most parts of India (Fig. 10) are similar to observed trends (Mitchell and Jones, 2005) for similar time periods (Fig. 11). However, a notable exception is the simulated increase over eastern India/Bangladesh obtained

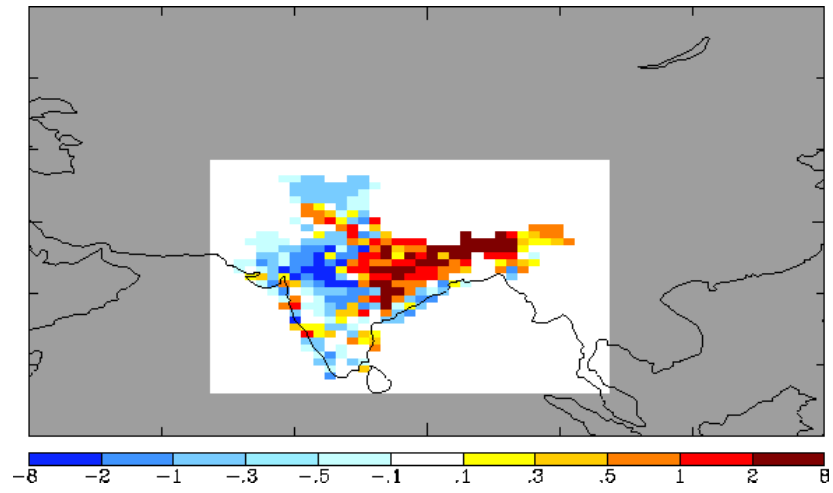

Fig. 12. Trend in summer (June to August) precipitation (in $\mathrm{mm} / \mathrm{d}$ ) from 1990 to 2000 using observations from the Indian Meteorological Department (IMD) data Rajeevan et al. (2006).

for simulations without the climate influence that is opposite to observed trends from the CRU TS2.0 data (shown in Fig. 11) but consistent with summer rainfall trends from the Indian Meteorological Department data (Rajeevan et al., 2006) for the 1990-2000 period. These observations indicate a decrease over much of central India but an increase over eastern India (Fig. 12).

The simulated spatial distribution of atmospheric water vapour and wind fields show that the increased precipitation 
over eastern India is from increased flow of moisture from the east, and for the future case, the moisture flow from the Arabian Sea causes the increase over central India. However, the number of stations in eastern and northern India are sparse compared to the southern parts (Rajeevan et al., 2006) and using the same data-set but for the 1950-2000 time period an increase in extreme rainfall events was found for India but with no strong trend otherwise (Goswami et al., 2006). Based on the uncertainty that exists with precipitation data, we suggest that the simulations with the Beig emissions best capture the decline over central India indicated by both rainfall observations and $\mathrm{BC}$ aerosols can influence extreme rainfall events, as indicated by the strong increase over east India (Fig. 8).

\section{Conclusions}

Although we do not preclude the influence of large-scale circulation or GHGs on the spatial patterns of precipitation or snow cover changes, our results indicate that aerosols and the enhanced Indian fossil/bio-fuel BC aerosols in particular may be responsible for some of the observed patterns and trends in snow/ice cover and precipitation. However, since we use prescribed SSTs in our simulations the climate response we simulate for the monsoon, especially near the ocean, may not fully account for feedbacks that occur when aerosols impact SSTs that could affect the spatial pattern of precipitation (Rotstayn and Lohmann, 2002). The range in climate impacts from the two emission inventories examined provide an estimate of the expected uncertainty in climate change from aerosols for the last decade (1990 to 2000) and illustrate future expected challenges from aerosols and $\mathrm{BC}$ emissions in particular. Preserving the present snow/ice cover on the third polar ice cap would require concerted efforts to reduce both GHGs and BC emissions from coal as well as transportation and residential cooking/heating sources.

Acknowledgements. This work was supported by the US Department of Energy under Contract No. DE-AC02-05CH11231at Lawrence Berkeley National Laboratory and under Contract DEAC52-07NA27344 at Lawrence Livermore National Laboratory. S. M. acknowledges support from the NASA MAP Program and the DOE Atmospheric Radiation Program and thanks Hugh Morrison (NCAR) and Igor Sednev (LBNL) for help with the cloud scheme used in the climate model and Nadine Unger (NASA GISS) for help with determining the statistical significance of the results.

Edited by: R. Krejci

\section{References}

Ackerman, A. S., Toon, O. B., Stevens, D. E., Heymsfield, A. J., Ramanathan, V., and Welton, E. J.: Reduction of tropical cloudiness by soot, Nature, 288, 1042-1047, 2000.

Armstrong, R. and Brodzik, M.: Northern Hemisphere EASE-Grid weekly snow cover and sea ice extent version 3. Boulder, Colorado USA, National Snow and Ice Data Center, Digital media, 2005.

Beegum, G. N., Moorthy, K. K., Babu, S. S., Sathhesh, S., Vinoj, V., Badarinath, K., Safai, P., Devara, P., Singh, S., Vinod, Dumka, U., and Pant, P.: Spatial distribution of aerosol black carbon over India during pre-monsoon season, Atmos. Environ., 43, 10711078, 2009.

Beheng, K.: A parametrization of warm cloud microphysical conversion processes, Atmos. Res., 33, 193-206, 1994.

Bond, T. C., Streets, D., Yarber, K., Nelson, S., Woo, J., and Klimont, Z.: A technology-based global inventory of black and organic carbon emissions from combustion, J. Geophys. Res., 109, D14203, doi:10.1029/2003JD003697, 2004.

Del Genio, A. D., Yao, M.-S., Kovari, W., and Lo, K.-W.: A prognostic cloud water parameterization for global climate models, J. Climate, 9, 270-304, 1996.

Del Genio, A. D., Kovari, W., Yao, M.-S., and Jonas, J.: Cumulus microphysics and climate sensitivity, J. Climate, 18, 2376-2387, 2005.

Economist: Melting Asia, Economist, June 5, 2008.

Etienne, B., Arnaud, Y., Kumar, R., Ahmad, S., Wagnon, P., and Chevallier, P.: Remote sensing estimates of glacier mass balances in the Himachal Pradesh (Western Himalalya, India)., Remote Sens. Env., 108, 327-338, 2007.

Flanner, M., Zender, C. S., Randerson, J., and Rasch, P.: Presentday climate forcing and response from black carbon in snow, J. Geophys. Res., 112, D11202, doi10.1029/2006JD008003, 2007.

Flanner, M. G., Zender, C. S., Hess, P. G., Mahowald, N. M., Painter, T. H., Ramanathan, V., and Rasch, P. J.: Springtime warming and reduced snow cover from carbonaceous particles, Atmos. Chem. Phys., 9, 2481-2497, doi:10.5194/acp-9-24812009, 2009.

Goes, J., Thoppil, P., Gomes, H., and Fasullo, J.: Warming of the Eurasian landmass is making the Arabian Sea more productive, Science, 308, 545-547, 2005.

Goswami, B., Venugopa, V., Sengupta, D., Madhusoodanan, M., and Xavier, P.: Increasing trend of extreme rain events over India in a warming environment, Science, 314, 1442-1445, 2006.

Hansen, J. and Nazarenko, L.: Soot climate forcing via snow and ice albedos, Proc. Natl. Acad. Sci., 101, 423-428, 2004.

Intergovernmental Panel on Climate Change: Climate Change 2007: The Physical Science Basis, Cambridge University Press, edited by: Solomon, S., Qin, D., Manning, M., Chen, Z., Marquis, M., Averyt, K. B., Tignor, M., and Miller, H. L., 2007.

Jacobson, M.: Climate response of fossil fuel and biofuel soot accounting for soot's feedback to snow and sea ice albedo and emissivity, J. Geophys. Res., 109, D21201, doi:10.1029/2004JD004945, 2004.

Jethva, H., Satheesh, S., and Srinivasan, J.: Seasonal variability of aerosols over the Indo-Gangetic basin, J. Geophys. Res., 110, D21204, doi:10.1029/2005JD005938, 2005.

Jones, A., Haywood, J., and Boucher, O.: Aerosol forcing, climate response and climate sensitivity in the Hadley 
Center climate model, J. Geophys. Res., 112, D20211, doi:10.1029/2007JD008688, 2007.

Koch, D., Bond, T., Streets, D., Unger, N., and van der Werf, G.: Global impacts of aerosols from particular source regions and sectors, J. Geophys. Res., 112, d02205, doi:10.1029/2005JD007024, 2007.

Koch, D., Menon, S., Del Genio, A., Warren, S., Ruedy, R., Alienov, I., and Schmidt, G.: Distinguishing aerosol impacts on climate over the past century, J. Climate, 22, 2659-2677, 2009a.

Koch, D., Schulz, M., Kinne, S., McNaughton, C., Spackman, J. R., Balkanski, Y., Bauer, S., Berntsen, T., Bond, T. C., Boucher, O., Chin, M., Clarke, A., De Luca, N., Dentener, F., Diehl, T., Dubovik, O., Easter, R., Fahey, D. W., Feichter, J., Fillmore, D., Freitag, S., Ghan, S., Ginoux, P., Gong, S., Horowitz, L., Iversen, T., Kirkevåg, A., Klimont, Z., Kondo, Y., Krol, M., Liu, X., Miller, R., Montanaro, V., Moteki, N., Myhre, G., Penner, J. E., Perlwitz, J., Pitari, G., Reddy, S., Sahu, L., Sakamoto, H., Schuster, G., Schwarz, J. P., Seland, Ø., Stier, P., Takegawa, N., Takemura, T., Textor, C., van Aardenne, J. A., and Zhao, Y.: Evaluation of black carbon estimations in global aerosol models, Atmos. Chem. Phys., 9, 9001-9026, doi:10.5194/acp-9-9001-2009, 2009b.

Lohmann, U., Stier, P., Hoose, C., Ferrachat, S., Kloster, S., Roeckner, E., and Zhang, J.: Cloud microphysics and aerosol indirect effects in the global climate model ECHAM5-HAM, Atmos. Chem. Phys., 7, 3425-3446, doi:10.5194/acp-7-3425-2007, 2007.

Menon, S.: Current uncertainties in assessing aerosol effects on climate, Ann. Rev. Environ. Resour., 29, 1-30, 2004.

Menon, S., Hansen, J., Nazarenko, L., and Luo, Y.: Climate effects of black carbon aerosols in China and India, Science, 297, 22502253, 2002.

Menon, S., Del Genio, A., Kaufman, Y., Bennartz, R., Koch, D., Loeb, N., and Orlikowski, D.: Analyzing signatures of aerosolcloud interactions from satellite retrievals and the GISS GCM to constrain the aerosol indirect effect, J. Geophys. Res., 113, D14S22, doi:10.1029/2007JD009442, 2008a.

Ming, J., Cachier, H., Xiao, C., Qin, D., Kang, S., Hou, S., and $\mathrm{Xu}, \mathrm{J}$.: Black carbon record based on a shallow Himalayan ice core and its climatic implications, Atmos. Chem. Phys., 8, 1343 1352, doi:10.5194/acp-8-1343-2008, 2008b.

Mitchell, T. and Jones, P.: An improved method of constructing a database of monthly climate observations and associated highresolution grids, Intl. J. Climatol., 25, 693-712, 2005.
Morrison, H. and Gettelman, A.: A new two-moment bulk stratiform cloud microphysics scheme in the Community Atmosphere Model, version 3 (CAM3). Part I: Description and numerial tests., J. Climate, 21, 3642-3659, 2008.

Ohmura, A.: Observed decadal variations in surface solar radiation and their causes, J. Geophys. Res., 114, D00D05, doi:10.1029/2008JD011290, 2009.

Rajeevan, M., Bhate, J., Kale, J., and Lal, B.: High resolution daily gridded rainfall data for the Indian region: Analysis of break and active monsoon spells, Current Sci., 91, 296-306, 2006.

Ramanathan, V. and Carmichael, G.: Global and regional climate change due to black carbon, Nature Geoscience, 1, 221-227, 2008.

Ramanathan, V., Chung, C., Kim, D., Bettge, T., Buja, L., Kiehl, J. T., Washington, W. M., Fu, Q., Sikka, D. R., and Wild, M.: Atmospheric brown clouds: Impacts on South Asian climate and hydrological cycle, Proc. Natl. Acad. Sci., 102(15), 5326-5333, 2005.

Ramanathan, V., Raman, M., Roberts, G., Kim, D., Corrigan, C., Chung, C., and Winker, D.: Warming trends in Asia amplified by brown cloud solar absorption, Nature, 448, 575-579, 2007.

Rayner, N., Parker, D., Horton, E., Folland, C., Alexander, L., Rowell, D., Kent, E., and Kaplan, A.: Global analyses of SST, sea ice and night marine air temperature since the late nineteenth century., J. Geophys. Res., 108, 4407, doi:10.1029/2002JD002670, 2003.

Rotstayn, L. and Lohmann, U.: Tropical rainfall trends and the indirect aerosol effect, J. Climate, 15, 2103-2116, 2002.

Sahu, S., Beig, G., and Sharma, C.: Decadal growth of black carbon emissions in India, Geophys. Res. Lett., 35, L02807, doi:10.1029/2007GL032333, 2008.

Schmidt, G. A., Ruedy, R., Hansen, J. E., Aleinov, I., and N. Bell et al.: Present day atmospheric simulations using GISS ModelE: Comparison to in-situ, satellite and reanalysis data, J. Climate, 19, 153-192, 2006.

Spencer, M., Holecek, J., Corrigan, C., Ramanathan, V., and Prather, K. A.: Size-resolved chemical composition of aerosol particles during a monsoonal transition period over the Indian Ocean, J. Geophys. Res., 113, D16305, doi10.1029/2007JD008657, 2008.

Venkataraman, C., Habib, G., Eiguren-Fernandez, A., A.H.Miguel, and Friedlander, S.: Residential biofuels in South Asia: Carbonaceous aerosol emissions and climate impacts, Science, 307, 1454-1456, 2005. 